\title{
Phytochemical Screening of White Turi (Sesbania grandiflora (L.) Pers.) Leaves Extract in Various Extraction Methods
}

\section{Skrining Fitokimia Ekstrak Daun Turi Putih (Sesbania Grandiflora (L.) Pers.) pada Variasi Metode Ekstraksi}

OPEN ACCESS ISSN 2580-7730 (online)

Edited by: Andika Aliviameita Reviewed by: Ary Andini

*Correspondence: Jamilatur Rohmah jamilaturrohmah@umsida.ac.id

Received: 19 Mei 2021 Accepted: 26 Juni 2021 Published: 31 Juli 2021

Citation:

Rohmah J, Saidi IA, Rofidah L, Novitasari F, Margareta FA (2021) Phytochemical Screening of White Turi (Sesbania grandiflora (L.) Pers.) Leaves Extract in Various Extraction Methods Medicra (Journal of Medical Laboratory Science/Technology). 4:1. doi: 10.21070/medicra.v4i1.1395

\author{
Jamilatur Rohmah ${ }^{1 *}$, Ida Agustini Saidí, Luthfiyah Rofidah ${ }^{1}$, Fia Novitasari ${ }^{1}$, Frida Amelia \\ Margareta $^{1}$ \\ ${ }^{1}$ Teknologi Laboratorium Medis, Fakultas IImu Kesehatan, Universitas Muhammadiyah Sidoarjo, Sidoarjo, Jawa Timur, \\ Indonesia. \\ ${ }^{2}$ Teknologi Hasil Pertanian, Fakultas Sains dan Teknologi, Universitas Muhammadiyah Sidoarjo, Sidoarjo, Jawa \\ Timur, Indonesia.
}

One of the Fabaceae family that has potential as medicinal plant is the white Turi plant (Sesbania grandiflora (L.) Pers.). The purpose of this study was to determine the content of secondary metabolites which can be extracted using a various extraction methods. The extraction method used are digestion, percolation, reflux, soxhlet, infusion, and decoction extraction. The Turi plants used come from Mojosari, Mojokerto.The results of the initial phytochemical screening of white Turi leaf extract (Sesbania grandiflora (L.) Pers.) Were extracts in six extraction methods containing alkaloids, saponins and tannins.In extracts using the digestion, soxhlet, and reflux method containing steroids.Meanwhile, the four extracts from the digestion, percolation, soxhlet, and reflux methods contain phenolic.And the infusion and decoction method extracts containing flavonoids and triterpenoids. The similarity of the phytochemical test results for each extract but with different intensity results.

Keywords: phytochemical, various extraction methods, white Turi (Sesbania grandiflora (L.) Pers.)

Salah satu family Fabaceae yang berpotensi sebagai tanaman obat yakni tanaman Turi putih (Sesbania grandiflora (L.) Pers.). Penelitian ini bertujuan untuk mengetahui kandungan senyawa metabolit sekunder yang dapat terekstrak dengan menggunakan metode ekstraksi yang bervariasi. Metode ekstraksi yang digunakan yaitu ekstraksi digesti, perkolasi, refluks, soxklet, infusa, dan dekokta.Tanaman Turi diperoleh dari desa Pekukuhan, Mojosari, Mojokerto. Hasil skrining awal fitokimia ekstrak daun Turi putih (Sesbania grandiflora (L.) Pers.) yaitu ekstrak pada ke enam metode ekstraksi mengandung alkaloid, saponin, dan tanin. Pada ekstrak dengan metode digesti, soklet, dan refluks mengandung steroid. Sedangkan pada empat ekstrak metode digesti, perkolasi, soklet, dan refluks mengandung fenolik. Dan pada ekstrak metode infusa dan dekokta mengandung flavonoid dan triterpenoid. Kandungan fitokimia yang dimiliki ekstrak beberapa terdapat kesamaan namun dengan intensitas hasil yang berbeda.

Kata Kunci: fitokimia, Turi putih (Sesbania grandiflora (L.) Pers.), variasi metode ekstraksi 


\section{PENDAHULUAN}

Keanekaragaman hayati merupakan suatu komponen yang mendukung kelangsungan bumi dan isinya termasuk manusia. Secara biogeografis Indonesia dilalui oleh garis Wallace dan Weber yang menjadikannya memiliki keanekaragaman hayati yang tinggi. Indonesia adalah negara megabiodiversitas dengan keanekaragaman flora lebih dari 80.000 spesies dan sekitar 40-50 \%-nya merupakan tumbuhan endemik USAID Indonesia (2019); Jiraungkoorskul and Jiraungkoorskul (2015). Banyaknya tumbuhan menjadikan masyarakat memanfaatkannya sebagai bahan makanan, bahan sandang dan bahan bangunan serta obat tradisional.

Obat tradisional adalah bahan atau ramuan bahan yang berasal dari mineral, hewan, serta tumbuhan yang secara turun-temurun telah dipergunakan sebagai obat Yuan et al. (2016). Pengobatan tradisional dengan bahan alami pada dewasa ini lebih banyak dilakukan karena banyak mengandung senyawa farmakologis yang efektif untuk menyembuhkan suatu penyakit dan efek negatif yang akan ditimbulkan sangat minim Krishnan (2018). Salah satu tanaman obat yang banyak tumbuh di Indonesia adalah famili Fabaceae Cronquistand and Takhtajan (1996).

Famili Fabaceae biasa disebut dengan Leguminosa. Famili Fabaceae memiliki beragam manfaat seperti antioksidan, antikanker, dan antibakteri. Tumbuhan Turi termasuk salah satu famili Fabaceae yang merupakan tumbuhan kacang-kacangan Wagh et al. (2009). Turi (Sesbania grandiflora (L.) Pers.) merupakan tumbuhan pepohonan yang banyak tumbuh di pedesaan dan ditanam di pematang, pekarangan, maupun dipinggir jalan Suita and Syamsuwida (2017). Manfaat dari tumbuhan Turi yakni dapat mengobati sakit kepala, batuk, hidung berlendir, memar, keseleo, beri-beri, radang tenggorokan, hingga memperbanyak produksi ASI Suita and Syamsuwida (2017); Orwa et al. (2009). Tumbuhan Turi secara umum mengandung protein, karbohidrat, glikosida, alkaloid, steroid, terpenoid, tanin, dan flavonoid Reji and Alphonse (2013). Sedangkan batang Turi mengandung senyawa metabolit sekunder seperti steroid, triterpenoid, alkaloid, saponin, tanin dan flavonoid Rohmah et al. (2018).

Penelitian perbandingan daya antioksidan ekstrak aseton daun dan batang Turi putih (Sesbania grandiflora (L.) Pers.) dengan metode DPPH telah dilakukan oleh Rohmah et al. (2018), menunjukkan bahwa daun Turi putih (metode maserasi) memiliki kandungan fitokimia alkaloid, flavonoid, saponin, steroid, triterpenoid, fenolik, dan tanin. Selain itu terdapat penelitian lain bahwa di dalam ekstrak etanol daun Turi putih terdapat senyawa aktif berupa saponin dan flavonoid Jiraungkoorskul and Jiraungkoorskul (2015).

Selain itu, penelitian yang sudah dilakukan tentang aktivitas antioksidan daun Turi putih (Sesbania grandiflora (L.) Pers.) pada berbagai pelarut ekstraksi (etanol, etil asetat, dan n-heksana) secara maserasi menunjukkan kandungan fitokimia daun Turi putih pada ekstrak etanol mengandung saponin, alkaloid, steroid, tannin, dan fenolik. Sedangkan pada ekstrak etil asetat mengandung steroid, tannin, dan alkaloid. Selanjutnya pada ekstrak n-heksana mengandung steroid, alkaloid, tannin, dan triterpenoid Rohmah et al. (2020). Namun, penelitian tersebut dilakukan melalui metode maserasi untuk perolehan ekstrak. Sehingga perlu dilakukan skrining fitokimia pada daun Turi putih menggunakan metode ekstraksi yang lain, yaitu dengan metode digesti, perkolasi, refluks, soxklet, infusa, dan dekokta.

\section{METODE}

Simplisia daun Turi putih (Sesbania grandiflora (L.) Pers.) dibuat dengan cara daun Turi putih segar, utuh, dan berwarna hijau tua sebanyak $10,5 \mathrm{~kg}$ dicuci dalam air mengalir hingga bersih dan dikering-anginkan. Daun kering yang diperoleh selanjutnya ditimbang dan dihaluskan, kemudian diayak dan diperoleh serbuk daun Turi yang selanjutnya disebut sebagai simplisia daun Turi putih. Serbuk daun kemudian ditimbang dan disimpan dalam wadah tertutup Azwanida (2016) untuk dilakukan proses selanjutnya.

Ekstraksi metode infusa dilakukan dengan cara: serbuk daun Turi ditimbang sebesar $100 \mathrm{mg}$ dan dipanaskan dalam panci infusa yang berisi $1000 \mathrm{~mL}$ aquades selama 15 menit pada suhu $90^{\circ} \mathrm{C}$ (larutan induk konsentrasi $1000 \mathrm{ppm}$ ). Hasil rebusan kemudian disaring dengan kertas saring rangkap dibantu vakum. Pembuatan infusa daun Turi konsentrasi 20, 40, 60, 80, dan 100 ppm dilakukan dengan proses pengenceran dari larutan induk Azwanida (2016).

Ekstraksi metode dekokta dilakukan dengan cara: serbuk daun Turi ditimbang sebesar $100 \mathrm{mg}$ dan dipanaskan dalam panci infusa yang berisi $1000 \mathrm{~mL}$ aquades selama 30 menit pada suhu $90^{\circ} \mathrm{C}$ (larutan induk konsentrasi $1000 \mathrm{ppm}$ ). Hasil rebusan kemudian disaring dengan kertas saring rangkap dibantu vakum. Pembuatan infusa daun Turi konsentrasi 20, $40,60,80$, dan 100 ppm dilakukan dengan proses pengenceran dari larutan induk Azwanida (2016).

Ekstraksi metode digesti dilakukan dengan cara: Serbuk daun Turi putih sebanyak 50 gram dimasukkan dalam wadah kaca lalu ditambahkan pelarut n-heksana dan direndam selama 24 jam. Selanjutnya diletakkan di atas hot plate dan dipanaskan pada suhu $40^{\circ} \mathrm{C}$. Sampel diaduk dengan menggunakan maserator pada kecepatan \pm 1000 rpm selama 2 jam. Kemudian hasil ekstraksi disaring menggunakan corong Buchner dan vacuum untuk memisahkan maserat dengan filtrat. Filtrat yang diperoleh selanjutnya dilakukan penguapan menggunakan penangas air untuk mendapatkan ekstrak kental Uddin et al. (2016).

Ekstraksi metode perkolasi dilakukan dengan cara serbuk daun Turi putih sebesar 50 gram dialiri dengan n-heksana (1:4) pada suhu kamar dengan laju alir diatur sebesar 1 $\mathrm{ml} /$ menit. Ditambahkan pelarut n-heksana yang baru dan ekstraksi diulang sampai ekstrak terakhir tidak berwarna. Ekstrak gabungan disaring dan filtrat diuapkan menggunakan rotary vacuum evaporator pada suhu $40-50^{\circ} \mathrm{C}$ hingga diperoleh ekstrak pekat. 
Ekstraksi metode refluks dilakukan dengan cara: sebanyak 50 gram serbuk sampel daun Turi putih dimasukkan ke dalam labu alas bulat yang telah diisi dengan pelarut $\mathrm{n}$-heksana sampai serbuk simplisia terendam kurang lebih $2 \mathrm{~cm}$ di atas permukaan simplisia, atau 2/3 volume labu. Kemudian alat refluks dirangkai. Aliran air ke kondensor dan pemanas dijalankan sesuai dengan suhu pelarut yang digunakan. Ekstraksi dilakukan selama 3-4 jam. Filtrat ditampung dalam wadah penampung dan dipekatkan dengan rotary vacuum evaporator.

Ekstraksi metode soxhlet dilakukan dengan cara: sebanyak 50 gram serbuk sampel daun Turi dimasukkan ke dalam klonsong yang telah dilapisi kertas saring (tinggi sampel dalam klongsong tidak boleh dari pipa sifon). Selanjutnya labu alas bulat diisi dengan pelarut n-heksana dan merangkai alat soxhlet. Aliran air ke kondensor dan pemanas dijalankan hingga terjadi proses ekstraksi zat aktif sampai sempurna (7 kali sirkulasi). Filtrat yang diperoleh dipekatkan dengan rotary vacuum evaporator kemudian diangin-anginkan hingga diperoleh ekstrak kental yang selanjutnya dilakukan uji fitokimia.

Uji skrining fitokimia dilakukan dengan prosedur yang mengacu pada Banu and Cathrine (2015) dan Harborne (1992) yang meliputi 7 uji yaitu alkaloid, tannin, saponin, flavonoid, triterpenoid, steroid, dan fenolik:

Uji alkaloid dilakukan dengan cara: ke enam ekstrak masing-masing diambil sebanyak $1 \mathrm{~mL}$ lalu ditambahkan kloroform dan $\mathrm{NH}_{3}$. Kemudian dipanaskan di atas penangas air. Pada masing-masing tabung reaksi ditambahkan $\mathrm{H}_{2} \mathrm{SO}_{4} 1$ tetes. Tabung pertama masing-masing ekstrak ditambahkan pereaksi Mayer. Tabung kedua masing-masing ekstrak ditambah pereaksi Wagner. Sedangkan tabung ketiga masingmasing ekstrak ditambahkan pereaksi Dragendroff.

Uji tanin (Pereaksi $\mathrm{FeCl}_{3}$ ) dilakukan dengan cara: ekstrak daun Turi putih pada berbagai metode ekstraksi masingmasieng diambil sebanyak $1 \mathrm{ml}$. Lalu dipanaskan selama beberapa menit dan ditambahkan beberapa tetes $\mathrm{FeCl}_{3} 1 \%$.

Uji saponin dilakukan dengan cara: ekstrak daun Turi putih pada berbagai metode ekstraksi masing-masing diambil sebanyak $1 \mathrm{ml}$ dan ditambah aquades $10 \mathrm{ml}$ lalu didihkan dalam penangas air. Campuran tersebut kemudian dikocok dan dibiarkan selama 15 menit.

Uji flavonoid dilakukan dengan cara: ekstrak daun Turi putih pada berbagai metode ekstraksi masing-masing diambil sebanyak $1 \mathrm{ml}$ dan ditambahkan etanol 70\% sebanyak $3 \mathrm{ml}$ lalu dikocok, dipanaskan dan dikocok kembali. Kemudian campuran disaring dan diambil filtratnya. Filtrat ditambahkan 0,1 gram serbuk $\mathrm{Mg}$ dan $\mathrm{HCl}$ pekat 3 tetes.

Uji triterpenoid (Uji Liebermann-Burchard) dilakukan dengan cara: ekstrak daun Turi putih pada berbagai metode ekstraksi masing-masing diambil sebanyak $1 \mathrm{ml}$ dan ditambahkan kloroform $2 \mathrm{ml}$ dan $\mathrm{H}_{2} \mathrm{SO}_{4}$ pekat $3 \mathrm{ml}$.

Uji steroid dilakukan dengan cara: Sampel ekstrak daun Turi putih pada berbagai metode ekstraksi masing-masing diambil sebanyak $1 \mathrm{ml}$ dan ditambahkan etanol $70 \%$ sebanyak $3 \mathrm{ml}$ dan $\mathrm{H}_{2} \mathrm{SO}_{4}$ pekat $2 \mathrm{ml}$ dan $\mathrm{CH}_{3} \mathrm{COOH}$.

Uji fenolik dilakukan dengan cara: sampel ekstrak daun Turi putih pada berbagai metode ekstraksi masing-masing diambil sebanyak $1 \mathrm{ml}$ dan ditambahkan $\mathrm{NaCl} 1 \%$ dan gelatin $10 \%$.

\section{HASIL DAN PEMBAHASAN}

Simplisia daun Turi putih yang digunakan dalam penelitian ini diperoleh dari desa Pekukuhan, Mojosari, Mojokerto. Pembuatan simplisia dilakukan dalam beberapa tahap yang meliputi tahap sortasi basah, sortasi kering dan penghalusan bahan Azwanida (2016); Sulasmi et al. (2016). Tahap sortasi basah merupakan tahap pencucian bahan dengan memisahkan bahan dari kotoran. Sedangkan tahap sortasi kering merupakan tahap pengurangan kadar air dan mencegah kerusakan simplisia akibat adanya pertumbuhan kapang melalui pengeringan dengan menggunakan sinar matahari tak langsung Sulasmi et al. (2016). Kemudian tahap penghalusan bahan merupakan tahapan akhir pembuatan simplisia sehingga didapatkan bahan dalam bentuk serbuk. Penghalusan bahan menjadi bentuk serbuk bertujuan untuk memperluas permukaan bahan sehingga meningkatkan interaksi bahan dengan pelarut dan mempermudah komponen bioaktif yang terkandung dalam simplisisa larut ke dalam pelarut Mtunzi et al. (2017). Simplisia daun Turi putih yang diperoleh berwarna hijau tua dengan aroma khas daun Turi. Hasil berat sampel daun Turi putih (Sesbania grandiflora (L.) Pers.) dapat dilihat pada Tabel 1.

Berdasarkan data pada Tabel 1, daun kering mengalami penyusutan sebesar 34,29\% dari daun basah. Penyusutan ini disebabkan karena menguapnya kadar air yang ada pada daun basah saat tahap sortasi kering. Tahap ini bertujuan untuk mencegah tumbuhnya kapang/mikroba/jamur sehingga kualitas simplisia terjaga serta simplisia tidak akan mudah membusuk Azwanida (2016).

Proses ekstraksi dilakukan dengan variasi metode ekstraksi yaitu metode infusa, dekokta, digesti, perkolasi, refluks, dan soxhlet. Simplisia daun Turi putih sebanyak 50 gram dalam pelarut n-heksana untuk metode digesti, perkolasi, refluks, dan soxhlet. Sedangkan untuk metode infusa dan dekokta pelarut yang digunakan yakni aquades.

Penggunaan simplisia daun dalam bentuk serbuk dimaksudkan untuk memperluas luas permukaan simplisia agar kontak/interaksi dengan pelarut akan semakin besar. Sehingga pelarut dapat mudah menembus dinding sel simplisia dan masuk ke rongga sel yang mengandung komponen bioaktif. Akibatnya komponen bioaktif yang terkandung dalam sampel akan larut karena adanya perbedaan konsentrasi atau tekanan di luar dan di dalam sel, sehingga larutan yang terpekat akan didesak ke luar. Maka dalam peristiwa tersebut larutan yang berada di dalam dan di luar sel terjadi keseimbangan konsentasi larutan Zhang et al. (2018). Oleh karena itu akan semakin banyak zat aktif yang akan ikut terbawa pelarut. Tujuan ekstraksi dengan berbagai metode 
ekstraksi yaitu untuk mengetahui metode ekstraksi yang manakah yang paling efektif dan menghasilkan rendemen yang paling tinggi sehingga dapat digunakan sebagai rujukan untuk mengetahui metode ekstraksi yang paling efektif dalam menarik komponen bioaktif yang ada pada simplisia Marliana et al. (2005).

Hasil ekstraksi digesti, perkolasi, refluks, dan soxhlet daun Turi putih dilakukan pengentalan dengan rotary vacum evaporator pada suhu $55^{\circ} \mathrm{C}$ sehingga didapatkan ekstrak pekat daun Turi putih. Sedangkan pada ekstraksi infusa dan dekokta dilakukan dengan tanpa pengentalan ekstrak. Hasil eksnvg VZX RT6 Xtrak dapat dilihat pada Tabel 2.

TABEL 1. Perolehan sampel daun Turi (Sesbania grandiflora (L.) Pers.)

\begin{tabular}{cccc}
\hline $\begin{array}{c}\text { Jenis } \\
\text { Sampel }\end{array}$ & Daun basah & $\begin{array}{c}\text { Parameter (gram) } \\
\text { Daun kering }\end{array}$ & Serbuk daun \\
Daun Turi & 4.000 & 2.000 & 1.500 \\
\hline
\end{tabular}

TABEL 2. Hasil Ekstrak Daun Turi (Sesbania grandiflora (L.) Pers.)

\begin{tabular}{llllllll}
\hline \multirow{2}{*}{ Sampel } & Parameter & Digesti & Perkolasi & Soxklet & Refluks & Infusa & Dekokta \\
& & & $50 \mathrm{gram}$ & $50 \mathrm{gram}$ & $50 \mathrm{gram}$ & $50 \mathrm{gram}$ & $50 \mathrm{gram}$ \\
& Serbuk simplisia & $50 \mathrm{gram}$ & & & & \\
Daun & Ekstrak pekat & $1,733 \mathrm{gram}$ & $0,922 \mathrm{gram}$ & $1,081 \mathrm{gram}$ & $1,412 \mathrm{gram}$ & - & - \\
& Rendemen & $3,47 \%$ & $1,84 \%$ & $2,162 \%$ & $2,824 \%$ & - & -
\end{tabular}

TABEL 3. Hasil Uji Skrining Awal Fitokimia Ekstrak Daun Turi Pada Berbagai Metode Ekstraksi

\begin{tabular}{|c|c|c|c|c|c|c|c|}
\hline \multirow{2}{*}{ Uji Fitokimia } & \multirow{2}{*}{ Pereaksi } & \multicolumn{3}{|c|}{ Kesimpulan Hasil (+) / (-) } & \multirow[b]{2}{*}{ Refluks } & \multirow[b]{2}{*}{ Infusa } & \multirow[b]{2}{*}{ Dekokta } \\
\hline & & Digesti & Perkolasi & Soxklet & & & \\
\hline Flavonoid & $\mathrm{Mg}+\mathrm{HCl}_{\text {pekat }}+$ etanol & - & - & - & - & ++ & ++ \\
\hline \multirow[t]{3}{*}{ Alkaloid } & Mayer & + & ++ & +++ & +++ & +++ & ++ \\
\hline & Wagner & ++ & ++ & +++ & ++ & ++ & + \\
\hline & Dragendorf & +++ & +++ & +++ & + & +++ & - \\
\hline Tanin & $\mathrm{FeCl}_{3} 1 \%$ & +++ & +++ & + & +++ & + & ++ \\
\hline Saponin & - & +++ & ++ & ++ & ++ & +++ & +++ \\
\hline Triterpenoid & Kloroform $+\mathrm{H}_{2} \mathrm{SO}_{4}$ pekat & - & - & - & - & +++ & +++ \\
\hline Steroid & Libermann-Burchard & +++ & - & +++ & +++ & - & - \\
\hline Fenolik & $\mathrm{NaCl} 10 \%$ + Gelatin 1\% & ++ & ++ & +++ & + & - & - \\
\hline
\end{tabular}

Berdasarkan pada Tabel 2 diperoleh \% rendemen ekstrak daun Turi putih pada berbagai metode ekstraksi. Persentase rendemen merupakan nilai yang menunjukkan perbandingan antara ekstrak yang didapat dengan simplisia dalam satuan persen $(\%)$. Urutan \% rendemen dari yang terbesar ke yang terkecil yaitu metode digesti, refluks, soxhlet, dan perkolasi. Metode digesti menghasilkan \% rendemen yang paling tinggi dibandingkan dengan metode ekstraksi yang lainnya, hal ini menunjukkan bahwa kandungan senyawa dalam daun Turi cenderung terekstrak dengan metode digesti. Perbedaan nilai rendemen tersebut diduga disebabkan oleh sifat metode ekstraksi dalam melarutkan senyawa metabolit sekunder yang berbeda Uddin et al. (2016).

Uji skrining awal fitokimia yang dilakukan pada ekstrak daun Turi putih (Sesbania grandiflora (L.) Pers.) pada berbagai metode ekstraksi meliputi uji flavonoid, alkaloid, tannin, saponin, triterpenoid, steroid, dan fenolik. Hasil uji fitokimia ekstrak daun Turi putih (Sesbania grandiflora (L.)
Pers.) dapat dilihat pada Tabel 3. Berdasarkan hasil pada Tabel 3, pada ekstrak digesti daun Turi putih (Sesbania grandiflora (L.) Pers.) menunjukkan uji positif untuk alkaloid, tannin, saponin, steroid, dan fenolik. Sedangkan pada ekstrak perkolasi daun Turi putih (Sesbania grandiflora (L.) Pers.) menunjukkan uji positif untuk alkaloid, tanin, saponin, dan fenolik. Dan pada ekstrak soxklet daun Turi putih (Sesbania grandiflora (L.) Pers.) menunjukkan uji positif untuk alkaloid, tannin, saponin, steroid, dan fenolik. Kemudian pada ekstrak refluks daun Turi putih menunjukkan uji positif untuk alkaloid, tannin, saponin, steroid, dan fenolik. Lalu pada ekstrak infusa dan dekokta daun Turi putih, kedua ekstrak menunjukkan uji positif untuk flavonoid, alkaloid, tannin, saponin, dan triterpenoid. Kandungan fitokimia yang dimiliki ekstrak beberapa terdapat kesamaan namun berbeda intensitas hasil yang diberikan. Berbedanya intensitas kandungan senyawa metabolit sekunder disebabkan karena adanya perbedaan metode ekstraksi yang digunakan. 
TABEL 4. Hasil Uji Fitokimia

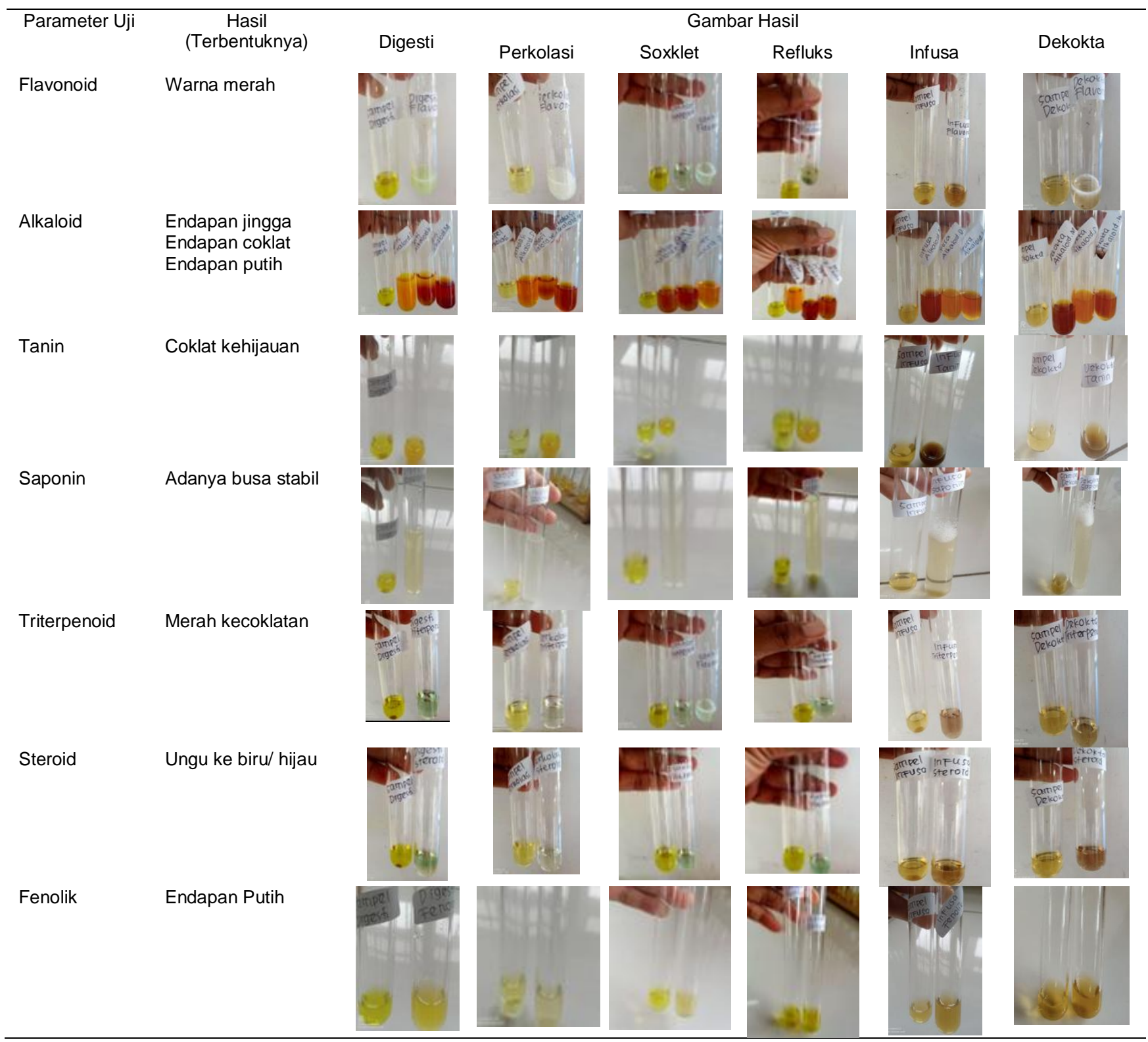

Berikut penjelasan setiap golongan senyawa pada tanaman Turi (Sesbania grandiflora (L.) Pers.) :

Uji Flavonoid. Berdasarkan hasil uji skrining fitokimia (Tabel 3 dan 4), ekstrak daun Turi putih (Sesbania grandiflora (L.) Pers.) menunjukkan tidak adanya senyawa flavonoid. Hasil uji flavonoid dikatakan positif apabila terbentuk endapan merah setelah penambahan pereaksi Tiwari et al. (2011). Hasil uji menunjukkan pada ekstrak metode infusa dan dekokta mengandung senyawa flavonoid.

$$
\begin{gathered}
\mathrm{Mg}_{(\mathrm{s})}+2 \mathrm{HCl}_{(\mathrm{aq})} \rightarrow \mathrm{MgCl}_{2(\mathrm{aq})}+\mathrm{H}_{2(\mathrm{~g})} \\
\mathrm{MgCl}_{2(\mathrm{aq})}+6 \mathrm{ArOH}_{(\mathrm{s})} \rightarrow\left[\mathrm{Mg}(\mathrm{OAr})_{6}\right]_{(\mathrm{aq})}^{4-}+6 \mathrm{H}^{+}+2 \mathrm{Cl}^{-}
\end{gathered}
$$

GAMBAR 1. Reaksi Uji Flavonoid Arista and Tukiran (2017)

Hal tersebut terjadi karena adanya reaksi oksidasi. Senyawa flavonoid dalam ekstrak teroksidasi oleh $\mathrm{Mg}^{2+}$ dan membentuk kompleks dengan ion magnesium (Arista, Setiabudi, Tukiran, 2017). Reaksi uji flavonoid ditunjukkan pada Gambar 1.

Uji Alkaloid, merupakan uji fitokimia menggunakan tiga pereaksi yaitu mayer, wagner, dan dragendorff. Hasil uji fitokimia alkaloid ekstrak daun Turi putih (Sesbania grandiflora (L.) Pers.) pada ke enam ekstrak menunjukkan hasil positif adanya senyawa alkaloid. Namun terdapat perbedaan intensitas hasil yang didapatkan, yaitu intensitas kuat pada ekstrak dengan metode soklet, refluks, dan infusa, sedangkan intensitas sedang ditunjukkan pada ekstrak perkolasi dan dekokta, serta intensitas rendah pada ekstrak digesti. Perbedaan intensitas warna endapan hasil uji menunjukkan banyaknya zat aktif yang dapat terekstrak dengan metode tersebut. Hasil positif adanya alkaloid dengan pereaksi mayer ditandai dengan terbentuknya endapan putih 
berupa senyawa kalium-alkaloid Setyowati et al. (2014). Berdasarkan pada Tabel 4, terbentuknya endapan putih karena adanya reaksi antara alkaloid dengan kalium tetraiodomerkurat membentuk endapan kompleks kaliumalkaloid berwarna putih. Gambaran reaksi alkaloid dengan pereaksi mayer ditunjukkan pada Gambar 2. Uji alkaloid dengan pereaksi wagner menghasilkan terbentuknya endapan coklat sampai kuning. Dimana endapan tersebut adalah kalium-alkaloid.

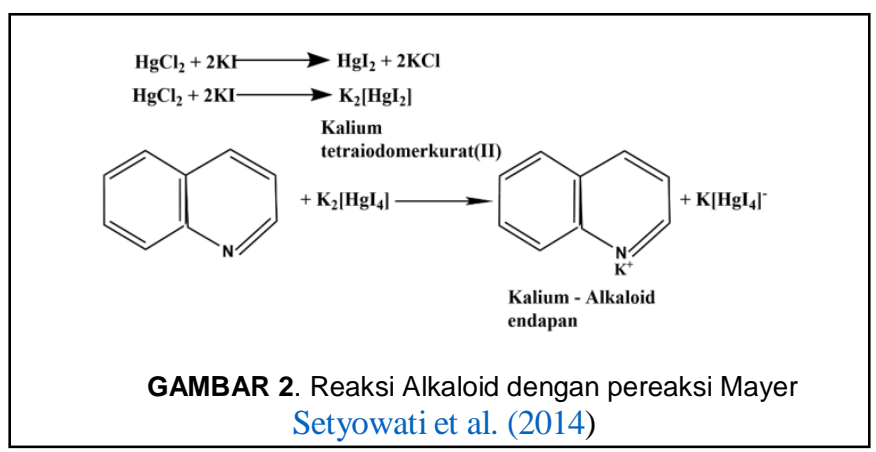

Berdasarkan pada Tabel 4, uji alkaloid dengan peraksi wagner terbentuk endapan coklat, sehingga dinyatakan ekstrak daun Turi pada berbagai metode ekstraksi mengandung alkaloid. Uji fitokimia alkaloid dengan pereaksi Mayer pada ke enam ekstrak menunjukkan perbedaan intensitas hasil yang didapatkan, yaitu intensitas kuat pada ekstrak dengan metode soklet, sedangkan intensitas sedang ditunjukkan pada ekstrak digesti, perkolasi, refluks, dan infusa, dan pada ekstrak dekokta menunjukkan intensitas yang rendah. Perbedaan intensitas warna endapan hasil uji menunjukkan banyaknya zat aktif yang dapat terekstrak dengan metode tersebut. Reaksi yang terjadi pada uji alkaloid dengan pereaksi wagner yaitu adanya ion $\mathrm{K}^{+}$terbentuk ikatan kovalen dengan nitrogen sehingga menghasilkan kompleks endapan alkaloid-kalium Tiwari et al. (2011). Gmbaran reaksi yang terjadi pada uji alkaloid dengan pereaksi wagner ditunjukkan pada Gambar 3.

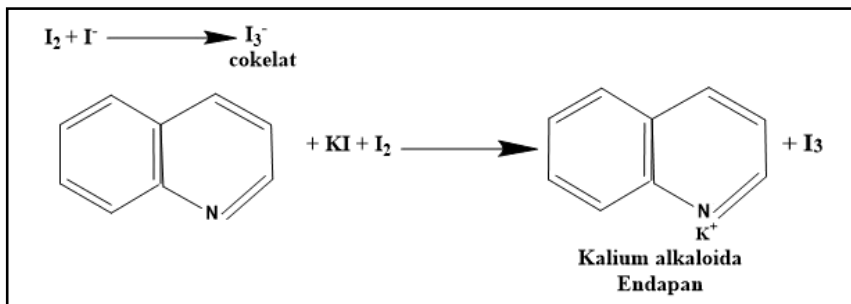

GAMBAR 3. Reaksi Alkaloid dengan Pereaksi Wagner Setyowati et al. (2014)

Uji alkaloid dengan pereaksi dragendorff membentuk endapan coklat muda hingga kuning berupa kompleks kalium-alkaloid. Hasil uji alkaloid dengan pereaksi dragendroff ditunjukkan pada Tabel 4. Reaksi yang terjadi pada uji alkaloid dragendorff yaitu adanya ikatan kovalen koordinat antara nitrogen dengan ion logam $\mathrm{K}^{+}$sehingga terbentuk endapan coklat muda hingga kuning Setyowati et al. (2014). Uji fitokimia alkaloid dengan pereaksi dragendorff pada ke enam ekstrak menunjukkan perbedaan intensitas hasil yang diperoleh, yaitu intensitas kuat pada ekstrak dengan metode digesti, perkolasi, soklet, dan infusa, sedangkan intensitas rendah ditunjukkan pada ekstrak refluks, dan pada ekstrak dekokta menunjukkan hasil negatif. Perbedaan intensitas warna endapan hasil uji menunjukkan banyaknya zat aktif yang dapat terekstrak dengan metode tersebut. Gambaran reaksi alkaloid dengan pereaksi dragendorff ditunjukkan pada Gambar 4.

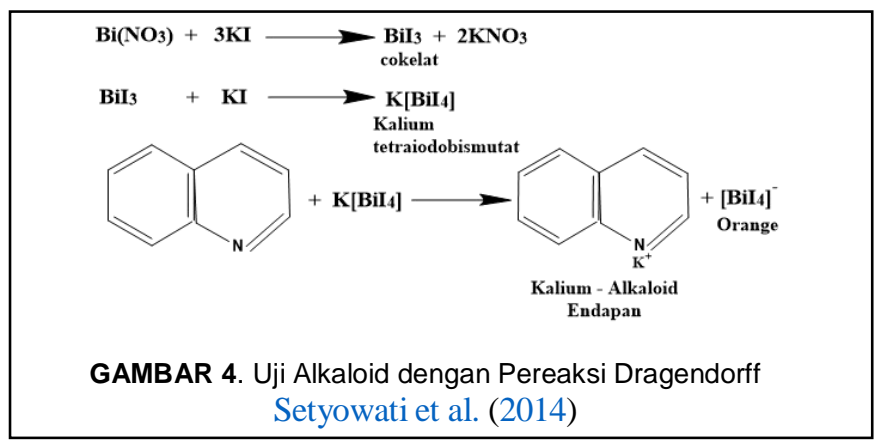

Uji Tanin. Pada uji fitokimia senyawa tanin, ekstrak daun Turi putih (Sesbania grandiflora (L.) Pers.) menunjukkan hasil positif pada ke semua ekstrak. Uji fitokimia tanin menggunakan pereaksi besi (III) klorida atau $\mathrm{FeCl}_{3}$. Terbentuknya warna biru/ hijau menunjukkan hasil positif tanin karena senyawa tanin bereaksi dengan ion $\mathrm{Fe}^{3+}$ membentuk kompleks. Hasil warna hijau tersebut digambarkan dengan reaksi uji fitokimia tanin ditunjukkan pada Gambar 5.

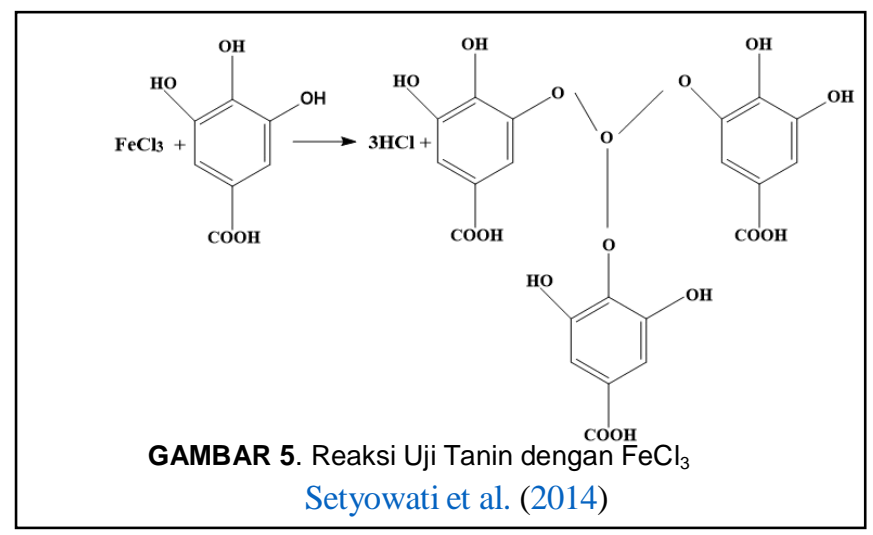

Uji Saponin. Uji fitokimia saponin pada ekstrak daun Turi putih (Sesbania grandiflora (L.) Pers.) menunjukkan hasil positif pada ke semua ekstrak yaitu dengan terbentuknya busa stabil pada saat dilakukan pengocokan. Hal ini terjadi karena adanya senyawa glikosida yang terhidrolisis menjadi glukosa dan senyawa lain sehingga dapat membentuk buih stabil 
Tiwari et al. (2011). Uji saponin pada ke enam ekstrak menunjukkan perbedaan intensitas hasil yang diperoleh, yaitu intensitas kuat pada ekstrak dengan metode digesti, infusa, dan dekokta, sedangkan intensitas sedang ditunjukkan pada ekstrak perkolasi, soklet, dan refluks. Perbedaan intensitas warna endapan hasil uji menunjukkan banyaknya zat aktif yang dapat terekstrak dengan metode tersebut.

Uji Steroid dan Triterpenoid pada ekstrak daun Turi putih (Sesbania grandiflora (L.) Pers.) pada berbagai metode ekstraksi menunjukkan hasil positif adanya steroid yaitu ekstrak dengan metode digesti, soklet, dan refluks. Hal ini ditunjukkan dengan adanya perubahan warna menjadi hijau kebiruan Marliana et al. (2005). Sedangkan pada uji triterpenoid, ekstrak metode infusa dan dekokta daun Turi putih (Sesbania grandiflora) menunjukkan hasil positif. Hal ini ditunjukkan dengan terbentuknya warna merah kecoklatan. Perubahan warna tersebut dapat terjadi karena adanya oksidasi membentuk ikatan terkonjugasi Harborne (1992). Gambaran reaksi yang terjadi pada uji steroid dan triterpenoid ditunjukkan pada Gambar 6.

\section{KESIMPULAN}

Ekstrak daun Turi putih (Sesbania grandiflora (L.) Pers.) pada berbagai metode ekstraksi memiliki kandungan fitokimia yang bervariasi. Pada ekstrak digesti daun Turi putih (Sesbania grandiflora (L.) Pers.) menunjukkan uji positif untuk alkaloid, tannin, saponin, steroid, dan fenolik. Sedangkan pada ekstrak perkolasi daun Turi putih (Sesbania grandiflora (L.) Pers.) menunjukkan uji positif untuk alkaloid, tanin, saponin, dan fenolik. Dan pada ekstrak soxklet daun Turi putih (Sesbania grandiflora (L.) Pers.) menunjukkan uji positif untuk alkaloid, tannin, saponin, steroid, dan fenolik. Kemudian pada ekstrak refluks daun Turi putih menunjukkan uji positif untuk alkaloid, tannin, saponin, steroid, dan fenolik. Lalu pada ekstrak infusa dan dekokta daun Turi putih, kedua ekstrak menunjukkan uji positif untuk flavonoid, alkaloid, tannin, saponin, dan triterpenoid.. Kandungan fitokimia yang dimiliki ekstrak beberapa terdapat kesamaan namun berbeda intensitas hasil yang berbeda.

\section{KONTRIBUSI PENULIS}

Penulis pertama berperan dalam pengumpulan data dan penyusunan artikel. Penulis kedua, ketiga, keempat dan kelima membantu dalam pengumpulan data dan penyusunan artikel.

\section{PENDANAAN}

Penelitian ini menggunakan dana pribadi dari peneliti.

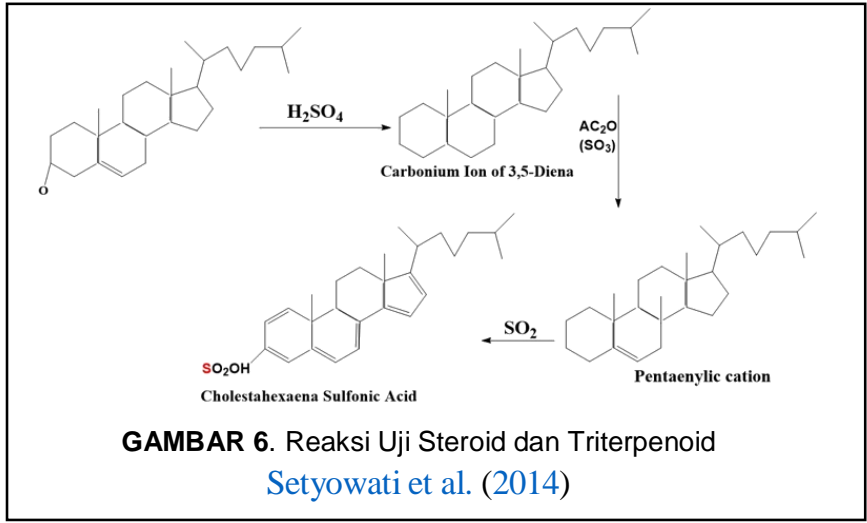

Uji Fenolik. Uji fitokimia fenolik pada ekstrak metode digesti, perkolasi, soklet, dan refluks daun Turi putih (Sesbania grandiflora (L.) Pers.) menunjukkan hasil positif. Hal ini ditunjukkan dengan terbentuknya warna coklat kehijauan. Menurut Harborne (1992), penggunaan $\mathrm{NaCl}$ berfungsi meningkatkan penggaraman dari senyawa fenol dan gelatin. Reaksi yang terjadi antara senyawa fenol dengan gelatin yaitu terbentuknya kopolimer yang tidak dapat larut dalam air.

\section{UCAPAN TERIMA KASIH}

Terima kasih disampaikan kepada desa Pekukuhan Mojosari Mojokerto atas sumber tanaman Turi (Sesbania grandiflora (L.) Pers.), Laboratorium TLM dan Laboratorium Kimia Organik Unesa sebagai penunjang metode dan fasilitas laboratorium yang digunakan dalam penelitian, tim penelitian Turi, serta kepada berbagai pihak yang membantu pelaksanaan penelitian.

\section{REFERENSI}

Arista, S. D., \& Tukiran. (2017). Uji Skrining Fitokimia Ekstrak Methanol Kulit Batang Tumbuhan Klampok Watu (Syzgium litorale). UNESA Journal of Chemistry, 6(3), 155-160. Retrieved from https://jurnalmahasiswa.unesa.ac.id/index.php/unesa-journal-ofchemistry/article/view/21991/20155.

Azwanida, N. N. (2016). A Review on the Extraction Methods Use in Medicinal Plants, Principle, Strength and Limitation. Medicinal \& Aromatic Plants, 4(3), 1-6. doi: 10.4172/2167-0412.1000196

Banu, K. S., \& Cathrine, L. (2015). General techniques involved in Phytochemical analysis. International Journal of Advanced Research in Chemical Science. 2(4), 25-32. Retrieved from https://www.arcjournals.org/pdfs/ijarcs/v2-i4/5.pdf

Cronquist, A., \& Takhtajan, A. (1996). An integrated system of classification of flowering plants, New York: Columbia University Press.

Harborne, J. B. (1992). Phytochemical methods, a guide to modern techniques of plant analysis. London, New York: Chapman and Hall.

Jiraungkoorskul, K., \& Jiraungkoorskul, W. (2015). Sesbania grandiflora: new nutraceutical use as antidiabetic. Int. J. Pharm. Pharm. Sci, 7( 7), 26-29. Retrieved from https://innovareacademics.in/journals/index.php/ijpps/article/view/6304/pdf $-900$ 
Krishnan, S. (2018). Traditional Herbal Medicines-A review. International Journal of Analytical Reviews (IJRAR) , 5(4), 611-614. Retrieved from https://www.researchgate.net/publication/331816204_TRADITIONAL_HE RBAL_MEDICINES_-_A_REVIEW.

Marliana, S., Suryanti, Suyono. (2005). Skrining Fitokimia dan Analisis Kromatografi Lapis Tipis Komponen Kimia Buah Labu Siam (Sechiumedule Jacq. Swartz.) dalam Ekstrak Etanol. Biofarmasi, 3 (1), 2631. Retrieved from https://eprints.uns.ac.id/843/1/196903131997022001bio_farmasi_6.pdf

Mtunzi, F. M., Ejidike, I. P., Matamela, T., Dikio, E., Klink, M. K. (2017). Phytochemical Profiling, Antioxidant and Antibacterial Activities of Leaf Extracts from Rhus leptodictya, International Journal of Pharmacognosy and Phytochemical Research, 9(8), 1090-1099. doi:10.25258/phyto.v9i08.9616.

Orwa, C., Mutua, A., Kindt, R., Jamnadass, R., \& Anthony, S. (2009). Agroforestree Database: a tree reference and selection guide version 4.0. World Agroforestry Centre, Kenya. Retrieved from http://apps.worldagroforestry.org/treedb/AFTPDFS/Sesbania_grandiflora.P DF.

Reji, A. F., \& Alphonse, N. R. (2013). Phytochemical study on Sesbania grandiflora. J. Chem. Pharm. Res. 5(4), 196-201. Retrieved from https://www.jocpr.com/articles/phytochemical-study-on-sesbaniagrandiflora.pdf.

Rohmah, J., Rachmawati, N. R., \& Nisak, S. (2018). Perbandingan daya antioksidan ekstrak aseton daun dan batang turi putih (Sesbania Grandiflora) dengan metode DPPH (diphenylpycrylhydrazyl). Prosiding Seminar Nasional Hasil Riset dan Pengabdian (SNHRP-I). 665-675. Retrieved from http://snhrp.unipasby.ac.id/wpcontent/uploads/2019/02/Prosiding-SNHRP-I-2018.pdf.

Rohmah, J., Saidi, I. A., Rini,C. S., Purwanto, Z. A. P., Tiana, K. H., \& Putri, T. C. R. (2020). Antioxidant activity assay of white Turi (Sesbania grandiflora (L.) Pers.) extracts using DPPH radical scavenging method. Pharmaciana, 10(3), 257-268. doi: 10.12928/pharmaciana.v10i3.16643.

Setyowati, W. A. E., Ariani, S. R. D., Ashadi., Mulyani, B., Rahmawati, C. P. (2014). Skrining Fitokimia dan Identifikasi Komponen Utama Ekstrak Metanol Kulit Durian (Durio zibethinus Murr.) Varietas Petruk. Jurnal Seminar Nasional Kimia dan Pendidikan Kimia VI, 271-280. Retrieved from https://adoc.pub/skrining-fitokimia-dan-identifikasi-komponen-utamaekstrak-m.html

Suita, E., \& Syamsuwida, D. (2017). Physical Characteristics and Germination Testing Methods of Turi (Sesbania grandiflora (L.) Pers) Seeds. Jurnal Perbenihan Tanaman Hutan, 5(2), 125-135. doi.org/10.20886/bptpth.2017.5.2.

Sulasmi, E. S., Indriwati, S. E., \& Suarsini, E. (2016). Preparation of Various Type of Medicinal Plants Simplicia as Material of Jamu Herbal, International Conference On Education (Education in the 21th Century: Responding to Current Issues). Retrieved from https://core.ac.uk/download/pdf/267023591.pdf.

Tiwari, P., Kumar, B., Kaur, M., Kaur, G., \& Kaur, H. (2011). Phytochemical screening and extraction: A review. Internationale Pharmaceutica Sciencia. 1(1), 98- $106 . \quad$ Retrieved from http://docshare01.docshare.tips/files/9403/94036813.pdf.

Uddin, A. B. M. H., Khalid, R. S., Alaama, M., Abdualkader, A. M., Kasmuri, A., \& Abbas, S. A. (2016). Comparative study of three digestion methods for elemental analysis in traditional medicine products using atomic absorption spectrometry. Journal of Analytical Science and technology, 7(6), 1-7. doi: 10.1186/s40543-016-0085-6.

USAID Indonesia (2019). Indonesia Tropical Forest And Biodiversity Analysis (FAA 118 \& 119) Report for Country Development Cooperation Strategy (CDCS) 2020-2025. Retrieved from https://pdf.usaid.gov/pdf_docs/PA00W7RT.pdf.

Wagh, D. V., Wagh, K. V., Tandale, Y. N., \& Salve, S. A. (2009). Phytochemical, Pharmacological and Phytopharmaceutics Aspects of Sesbania grandiflora (Hadga). Journal of Pharmacy Research, 2(5), 889-92. Retrieved from https://jprsolutions.info/files/final-file56b094bb159a07.61085079.pdf.
Yuan, H., Ma, Q., Ye, L., \& Piao, G. (2016). The Traditional Medicine and Modern Medicine from Natural Products. Molecules, 21(5), 559. doi:10.3390/molecules21050559.

Zhang, Q. W., Lin, L. G., \& Ye, W. C. (2018). Techniques for extraction and isolation of natural products: a comprehensive review. Chinese Medicine, 13(20). doi: 10.1186/s13020-018-0177-x.

Conflict of Interest Statement: The authors declare that the research was conducted in the absence of any commercial or financial relationships that could be construed as a potential conflict of interest.

Copyright (C) 2021 Rohmah, Saidi, Rofidah, Novitasari, Margareta. This is an openaccess article distributed under the terms of the Creative Commons Attribution License (CC BY). The use, dis- tribution or reproduction in other forums is permitted, provided the original author(s) and the copyright owner(s) are credited and that the original publication in this jour- nal is cited, in accordance with accepted academic practice. No use, distribution or reproduction is permitted which does not comply with these terms. 